\title{
Anthropometric and Somatotype Characteristics of Women with Breast Cancer
}

\author{
Características Antropométricas y Somatotipos de Mujeres con Cáncer de Mama
}

${\text { Udicki Mirjana'; Adamovic Dragan'; Srdic Galic Biljana }{ }^{1} \text {; Pavlica Tatjana }{ }^{2} \text { \& Radovanovic Zoran }}^{3,4}$

UDICKI, M.; ADAMOVIC, D.; SRDIC GaliC, B.; PAVLICA, T. \& RADOVANOVIC, Z. Anthropometric and somatotype characteristics of women with breast cancer. Int. J. Morphol., 38(2):448-457, 2020.

SUMMARY: Inconsistent data are available on the relation between breast cancer, adiposity, body size and somatotype. The aim of our study was to compare anthropometric characteristics, body composition and somatotype between breast cancer patients and healthy controls. Study group consisted of 106 breast cancer patients while control group consisted of 100 healthy women who underwent 29 anthropometric measurements. Women with breast cancer expressed more male anthropometric features like higher stature (160.75 \pm 6.91 vs. $158.17 \pm 4.89 \mathrm{~cm}, \mathrm{p}=0.020$ ), shorter trunk (sitting height in premenopausal: $84.94 \pm 5.07 \mathrm{vs} .88 .50 \pm 3.84 \mathrm{~cm}$, $\mathrm{p}=0.001$ and postmenopausal women: $81.96 \pm 6.08$ vs. $85.19 \pm 3.36 \mathrm{~cm}, \mathrm{p}=0.001)$, narrower hips $(29.20 \pm 3.78 \mathrm{vs} .32 .24 \pm 1.78 \mathrm{~cm}, \mathrm{p}=0.000)$, higher biepicondylar diameter of humerus (premenopausal: $6.64 \pm 0.71$ vs. $6.31 \pm 0.42 \mathrm{~cm}, \mathrm{p}=0.012$; postmenopausal: $6.95 \pm 0.63$ vs. $6.54 \pm 0.49 \mathrm{~cm}, \mathrm{p}=0.000$ ), larger upper- and forearm as well as upper thigh circumferences followed by lower biceps and higher thigh skinfold thicknesses. They also had significantly lower endomorphy (premenopausal: $5.84 \pm 1.78$ vs. $6.55 \pm 0.96, p=0.027$; postmenopausal: $6.89 \pm 1.52$ vs. $7.37 \pm 0.86, p=0.035$ ) and significantly higher ectomorphy (premenopausal: $2.05 \pm 1.30$ vs. $1.41 \pm 0.99, p=0.018$; postmenopausal: $1.06 \pm 0.90$ vs. $0.68 \pm 0.56$, $\mathrm{p}=0.007)$, as well as higher mesomorphy only in postmenopausal women $(6.10 \pm 2.04$ vs. $5.37 \pm 1.34, \mathrm{p}=0.022)$. Most represented somatotype among breast cancer patients was endomorph-mesomorph while the most healthy controls were mesomorphic endomorph. Android body type increases the risk of development of breast cancer. Indicators of skeletal dimensions, muscle volume and peripheral adiposity had better predictive value over markers of central and overall adiposity.

\section{KEY WORDS: Breast cancer; Obesity; Anthropometry; Somatotype.}

\section{INTRODUCTION}

Breast cancer represents one of the major health problems worldwide, since it has been the most common malignant disease in women. The number of newly diagnosed breast cancer patients in 2012 was 1.67 million of women which was $20 \%$ more when compared to year 2008 (IARC, 2015). According to the data given in the National Guideline of Good Clinical Practice for Breast Cancer Diagnose and Treatment the average standardized incidence rate of breast cancer in central Serbia in the period from 1999 to 2009 was $60.8 / 100000$ and the mortality rate was 20.2/100000 (National Guideline of Good Clinical Practice for Breast Cancer Diagnose and Treatment, 2013).

Besides well established risk factors such as female sex, age, positive family history, BRCA 1 and BRCA 2 gene mutations, previously diagnosed breast cancer or proliferative breast changes (including atypical hyperplasia), greater density of breast gland tissue, obesity, hormonal factors causing early menarche and late menopause or contraception use, and exposure to radiation especially during puberty, some researchers have tried to determine specific body constitution susceptible to breast cancer development (Harvie et al., 2003; Lahmann et al., 2004; Tehard \& Clavel-Chapelon, 2006; Rose \&VonaDavis, 2010; Amadou et al., 2013b; Pacholczak et al., 2016). The majority of these studies highlighted obesity as a risk factor, while others focused on height, leg length and overall body size (van den Brandt et al., 2000; Friedenreich, 2001; Lahmann et al.; Fagherazzi et al., 2012; Pacholczak et al.). Obesity has been considered to be a risk factor for breast cancer in postmenopausal women while in premenopausal women it could have a protective role (Bulun et al., 1994; Ursin et al., 1995; van den Brandt et al.; Lorincz \& Sukumar, 2006; Rose \& Vona-Davis;

\footnotetext{
${ }^{1}$ Department of Anatomy, Faculty of Medicine, University of Novi Sad, Hajduk Veljkova 3, 21000 Novi Sad, Serbia.

${ }^{2}$ Department of Biology and Ecology, Faculty of Sciences, University of Novi Sad, Trg Dositej Obradovic 2, 21000 Novi Sad, Serbia.

${ }^{3}$ Faculty of Medicine, University of Novi Sad, Hajduk Veljkova 3, 21000 Novi Sad, Serbia.

${ }^{3}$ Oncology Institute of Vojvodina, Put doktora Goldmana 4, Sremska Kamenica, Serbia.
} 
Zunurain et al., 2016). The relationship between obesity and breast cancer in postmenopausal women has been explained by the fact that adipose tissue is the main place for peripheral conversion of androgen precursor to estradiol under the influence of aromatase. Obesity-associated lowgrade inflammation and adipose tissue dysfunction that includes alterations in adipocytokines production promote the development and cancer progression (Divella et al., 2016). Only few studies have analyzed body constitution of women with breast cancer highlighting their android characteristics (Butova et al., 2005; Ronco et al., 2008), while two studies dealed with their somatotype characteristics (Butova et al.; Ronco et al.).

In view of the breast cancer as a global public health concern, the aim of our study was to compare the anthropometric characteristics, body composition and somatotype between women diagnosed with breast cancer and healthy women and to define the specific anthropometric profile of women with breast cancer.

\section{MATERIAL AND METHOD}

The study group included 106 women diagnosed with breast cancer aged $29-86$ years $(59.05 \pm 11.69$ years $)$, while control group consisted of 100 healthy women aged 19-82 years ( $51.10 \pm 15.73$ years). Women with breast cancer were measured at the Oncology Institute of Vojvodina in Sremska Kamenica prior to surgical tumor removal, while the healthy women were recruited among the medical staff and students of the Faculty of Medicine Novi Sad. All breast cancer patients were newly diagnosed who did not receive chemo, radio- or hormonal therapy. The research was approved by Ethical Committee and Expert Council of Oncology Institute of Vojvodina in Sremska Kamenica. All the respondents were given the detailed explanation about the purpose of the research and had signed the informed consent.

All participants were divided in two groups according to their menopausal status: premenopausal and postmenopausal. Anamnestic obtained data on the absence of menstrual bleeding for more than a year was used as criteria for menopause. Research group included 30 premenopausal and 76 postmenopausal women, while control group counted 46 premenopausal and 54 postmenopausal women. Histopathological examination of the surgically removed tissue revealed the presence of invasive ductal carcinoma in $84.91 \%$, invasive lobular carcinoma in $10.38 \%$, mixed ductal and lobular carcinoma in $2.83 \%$ and phyllodes tumor in $1.88 \%$ of women with breast cancer.

\section{Anthropometric measurements}

All subjects underwent 29 anthropometric measurements in order to assess longitudinal and transverse dimensionality of the body, body composition, nutritional status, body fat distribution and somatotype. Standing body height and sitting body height were used as parameters of longitudinal dimensionality of the body, while shoulder and hip width and bone diameters were measured to assess transverse dimensionality. Body weight, fat mass, body mass index (BMI), body adiposity index (BAI), body circumferences, skinfold thicknesses and sagittal abdominal diameter were used to assess body composition and fat distribution pattern.

Body height (standing and sitting) were measured by GPM anthropometer (Sieber \& Hegner, Zürich, Switzerland) to the nearest $0.1 \mathrm{~cm}$. Body height was measured in an upright position as a distance between the vertex and the floor when the head was placed in Frankfurt plane. Sitting height was measured from the sitting platform to the vertex when the head was held in the Frankfurt plane. Relative trunk length (Cormic index) was calculated as the ratio between sitting and standing height.

Measurements of body girths included upper arm (flexed and relaxed), forearm, thigh, calf, chest, waist and hip girth were done using Holtain flexible but non-stretchable tape (Holtain Ltd, Croswell, UK) to the nearest $0.1 \mathrm{~cm}$. Upper arm girth was measured at the level of mid-acromiale-radiale with flexed and relaxed elbow. Forearm girth was measured as maximal girth of the forearm approximately $5 \mathrm{~cm}$ below the elbow. Neck girth was measured immediately superior to the thyroid cartilage while the head was in Frankfurt plane. Thigh girth was measured as upper (between the upper and middle third of thigh), middle (at mid-trochanterion-tibiale laterale site) and lower (just above the knee). Calf girth was measured as the greatest girth of the calf. Chest girth was measured at the level of mesosternale. Waist girth was measured at the level midway between the lowest point of the rib margin and the highest point of the iliac crest. Hip girth was measured at the level of the greatest posterior protuberance of the buttocks which corresponded anteriorly to the level of symphysis pubis.

Harpenden skinfold caliper (Holtain Ltd, Croswell, UK) to the nearest $0.2 \mathrm{~mm}$ was used for measuring the thicknesses of following skinfolds: triceps, biceps, anterior and lateral forearm, subscapular, supraspinal, abdominal, thigh and calf. All measurements of the skinfold thicknesses were done on the right side of the body in triplicate and average score was calculated. Triceps skinfold thickness was measured in the vertical direction at the level halfway 
between the acromion and olecranon. Biceps skinfold thickness was measured in the vertical direction at the same level where triceps skinfold was measured just at the front side of the upper arm. Anterior and lateral forearm skinfold thicknesses were measured at the upper third of front and lateral side of forearm. Subscapular skinfold thickness was measured below the inferior angle of the scapula in an oblique direction downwards and laterally at 45 degrees. Supraspinal skinfold thickness was measured above the anterior superior iliac spine on a line to the anterior axillary margin and on a diagonal line going downwards and medially at 45 degrees. Abdominal skinfold thickness was measured as a vertical fold $3 \mathrm{~cm}$ lateral and $1 \mathrm{~cm}$ below umbilicus. Thigh skinfold thickness was a vertical fold measured on the middle third of front side of thigh. Calf skinfold thickness was measured in the vertical direction on the medial side of the leg, at the level of the maximum calf girth.

Biepicondylar diameter of humerus and biepicondylar diameter of femur were measured using Holtain bicondylar caliper (Holtain Ltd, Croswell, UK) to the nearest $0.1 \mathrm{~cm}$, sagittal abdominal diameter was measured using HoltainKahn abdominal caliper (Holtain Ltd, Croswell, UK), to the nearest $0.1 \mathrm{~cm}$, while biacromial shoulder width and hip width were measured by upper section of anthropometer. Biepicondylar diameter of humerus and femur were measured between lateral and medial epicondylus of humerus and femur. Shoulder width was measured between the most lateral points on the acromion process (acromiale) and hip width was measured as the most lateral points on the iliac crests (bi-iliocristal diameter). Sagittal abdominal diameter was measured as an anteroposterior diameter of abdomen at the level of iliac crests.

In order to assess the nutritional status, body mass index (BMI) and body adiposity index (BAI) were calculated. Body mass index was calculated as the ratio of the weight of the body in kilograms to the square of its height in meters, while body adiposity index (BAI) was calculated using the equation given by Bergman et al. (2011). Bioelectric impedance analyzer Omron BF-511 (Omron Matsusaka Co, Ltd, Matsusaka, Japan) was used for estimation of body fat percent $(\mathrm{BF} \%)$ and body fat mass $(\mathrm{kg})$.

In the assessment of somatotype, the Heath \& Carter method was used (Carter \& Heath, 1990). Standard procedures were used for endo-, meso- and ectomorphy calculations and somatotype was defined according to the position of calculated values of endo-, ecto- and mesomorphy on the somatochart (Eston \& Reilly, 2001).

Fat distribution was assessed according to the values of skinfold thicknesses and body circumferences and following ratios: waist to hip ratio (WHR), waist to stature ratio (WSR), waist to thigh ratio (WTR), abdominal diameter index (ADI) - ratio of the sagittal abdominal diameter and middle girth of the thigh, and body shape index (BSI) derived from waist girth adjusted for height and weight (Krakauer \& Krakauer, 2012).

The results were statistically processed in software program SPSS 24.0. Differences between case and control groups were determined by multivariate analysis of variance (MANOVA). Data in the text and tables are presented as mean values \pm SD. Differences were considered statistically significant if $\mathrm{p}$ level was less than 0.05 .

\section{RESULTS}

Reproductive characteristics of women in case and control group are represented in the Table I. Premenopausal women diagnosed with breast cancer had significantly higher number of pregnancies compared to the controls $(2.37 \pm 1.50$ vs. $1.57 \pm 1.21, \mathrm{p}=0.012$ ).

Table I. Comparison of case and control group on reproductive characteristics.

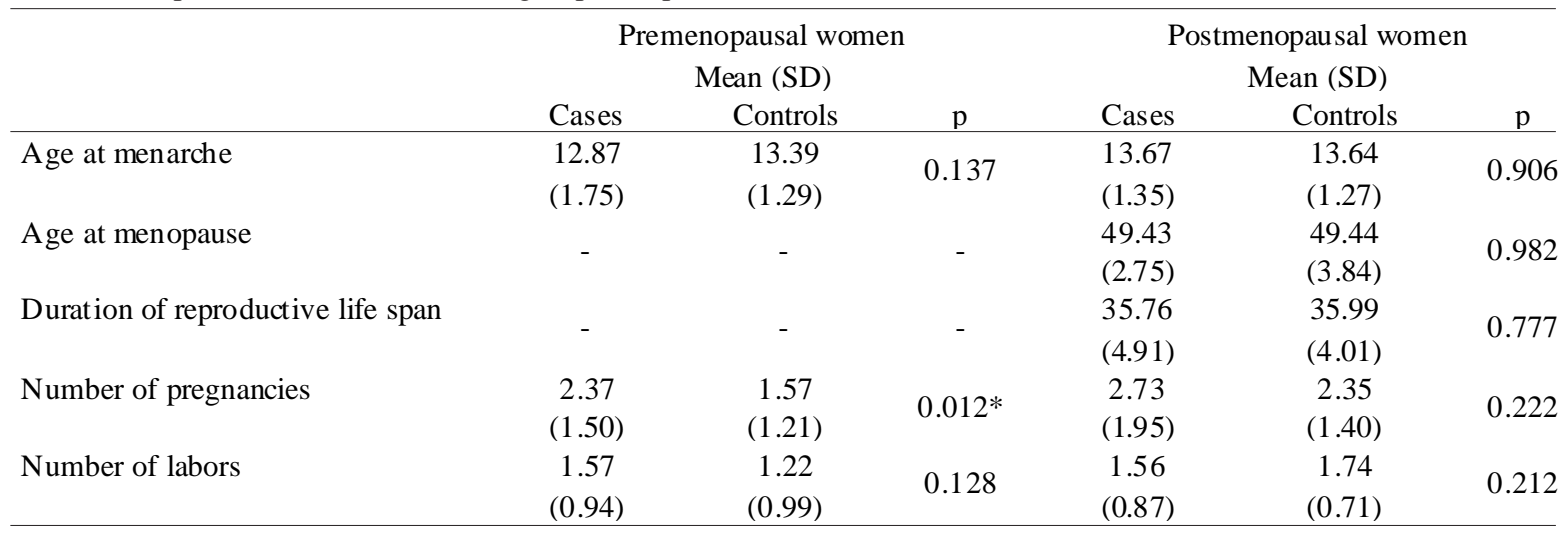


The results of comparison between the case and control group on the anthropometric parameters of body dimensionality are displayed in the Table II. Standing body height was significantly greater in the postmenopausal women with breast cancer $(160.75 \pm 6.91$ vs. $158.17 \pm 4.89 \mathrm{~cm}$, $\mathrm{p}=0.020$ ), while the sitting body height was significantly lesser in all breast cancer patients (premenopausal: $84.94 \pm 5.07 \mathrm{vs}$. $88.50 \pm 3.84 \mathrm{~cm}, \mathrm{p}=0.001$; postmenopausal: $81.96 \pm 6.08 \mathrm{vs}$. $85.19 \pm 3.36 \mathrm{~cm}, \mathrm{p}=0.001$ ), as well as the Cormic index (premenopausal: $51.06 \pm 3.09$ vs. $54.03 \pm 1.05, \mathrm{p}=0.000$; postmenopausal: $50.99 \pm 3.08$ vs. $53.85 \pm 1.01, \mathrm{p}=0.000)$.

Among parameters of transverse dimensionality women with breast cancer had significantly larger diameter of humerus than healthy controls (premenopausal: 6.64 \pm 0.71 vs. $6.31 \pm 0.42 \mathrm{~cm}, \mathrm{p}=0.012$; postmenopausal: $6.95 \pm 0.63$ vs. $6.54 \pm 0.49 \mathrm{~cm}, \mathrm{p}=0.000)$, while premenopausal breast cancer patients had significantly narrower hips $(29.20 \pm 3.78$ vs. $32.24 \pm 1.78 \mathrm{~cm}, \mathrm{p}=0.000$ ) and smaller biepicondylar diameter of femur $(9.98 \pm 0.63$ vs. $10.28 \pm 0.54 \mathrm{~cm}, \mathrm{p}=0.029)$ than controls.

Values of body composition parameters in the case and control group are given in the Table III. Both, premenopausal and postmenopausal women with breast cancer had significantly lower BMI values when compared to controls (premenopausal: $23.56 \pm 3.54$ vs. $26.03 \pm 5.16 \mathrm{~kg}$ / $\mathrm{m}^{2}, \mathrm{p}=0.025$; postmenopausal: $27.60 \pm 5.19$ vs. $29.91 \pm 4.59$ $\left.\mathrm{kg} / \mathrm{m}^{2}, \mathrm{p}=0.010\right)$. Postmenopausal women with breast cancer had significantly lower BAI values than controls (33.53 \pm 5.74 vs. $\left.36.40 \pm 5.74 \mathrm{~kg} / \mathrm{m}^{2}, \mathrm{p}=0.005\right)$.

Premenopausal and postmenopausal breast cancer patients had significantly higher relaxed and flexed upper arm circumference (relaxed: premenopausal: $26.93 \pm 3.28$ vs. $24.53 \pm 3.29 \mathrm{~cm}, \mathrm{p}=0.003$; postmenopausal: $28.90 \pm 3.65 \mathrm{vs}$. $25.47 \pm 3.21 \mathrm{~cm}, \mathrm{p}=0.000$; flexed: premenopausal: $27.83 \pm 3.38$ vs. $25.07 \pm 3.34 \mathrm{~cm}, \mathrm{p}=0.001$; postmenopausal: $29.79 \pm 3.97$ vs. $26.09 \pm 3.29 \mathrm{~cm}, \mathrm{p}=0.000)$, forearm circumference (premenopausal: $23.78 \pm 1.95$ vs. $21.91 \pm 2.08 \mathrm{~cm}, \mathrm{p}=0.000$; postmenopausal: $24.54 \pm 2.66$ vs. $22.71 \pm 2.08 \mathrm{~cm}, \mathrm{p}=0.000$ ), and upper thigh circumference (premenopausal: 55.11 \pm 5.05 vs. $51.24 \pm 5.51 \mathrm{~cm}, \mathrm{p}=0.003$; postmenopausal: $54.77 \pm 6.43$ vs. $51.59 \pm 4.39 \mathrm{~cm}, \mathrm{p}=0.002$ ). Hip circumference was nearly significantly lower only in postmenopausal breast cancer patients $(104.68 \pm 9.50$ vs. $108.02 \pm 9.95 \mathrm{~cm}, \mathrm{p}=0.055)$, and lower thigh circumference was significantly lower in premenopausal breast cancer patients $(41.88 \pm 3.27$ vs. $44.02 \pm 3.86 \mathrm{~cm}, \mathrm{p}=0.014)$.

Thigh skinfold thickness was significantly higher in breast cancer patients (premenopausal: 39.74 \pm 11.23 vs. $31.60 \pm 5.77 \mathrm{~mm}, \mathrm{p}=0.000$; postmenopausal: $41.18 \pm 10.89 \mathrm{vs}$. $33.21 \pm 6.86 \mathrm{~mm}, \mathrm{p}=0.000$ ), while abdominal skinfold thickness was significantly lower (premenopausal: $24.44 \pm 9.26$ vs. $29.73 \pm 6.47 \mathrm{~mm}, \mathrm{p}=0.004$; postmenopausal: $30.63 \pm 10.20$ vs. $35.02 \pm 6.33 \mathrm{~mm}, \mathrm{p}=0.006$ ), as well as supraspinal (premenopausal: $17.50 \pm 8.32$ vs. $23.53 \pm 6.23 \mathrm{~mm}$, $\mathrm{p}=0.001$; postmenopausal: $21.76 \pm 8.47$ vs. $28.47 \pm 5.60 \mathrm{~mm}$, $\mathrm{p}=0.000$ ) and biceps skinfold thicknesses (premenopausal: $14.47 \pm 6.05$ vs. $18.87 \pm 5.47 \mathrm{~mm}, \mathrm{p}=0.002$.

Among anthropometric indicators of central fat distribution only WTR was significantly lower in breast cancer women (premenopausal: $1.45 \pm 0.13$ vs. $1.59 \pm 0.27$, $\mathrm{p}=0.012$; postmenopausal: $1.64 \pm 0.30$ vs. $1.79 \pm 0.26$, $\mathrm{p}=0.003$ ).

Table IV represents the values of somatotype components in the case and control group. Women with breast cancer had significantly lower endomorphy (premenopausal: $5.84 \pm 1.78$ vs. $6.55 \pm 0.96, \mathrm{p}=0.027$; postmenopausal: $6.89 \pm 1.52$ vs. $7.37 \pm 0.86, \mathrm{p}=0.035)$ and significantly higher ectomorphy (premenopausal: $2.05 \pm 1.30$ vs. $1.41 \pm 0.99, \mathrm{p}=0.018$; postmenopausal: $1.06 \pm 0.90$ vs. $0.68 \pm 0.56, p=0.007)$. Mesomorphy was significantly higher only in the group of postmenopausal women $(6.10 \pm 2.04 \mathrm{vs}$. $5.37 \pm 1.34, \mathrm{p}=0.022)$.

Table II. Comparison of case and control group on anthropometric parameters of longitudinal and transversal skeletal dimensionality.

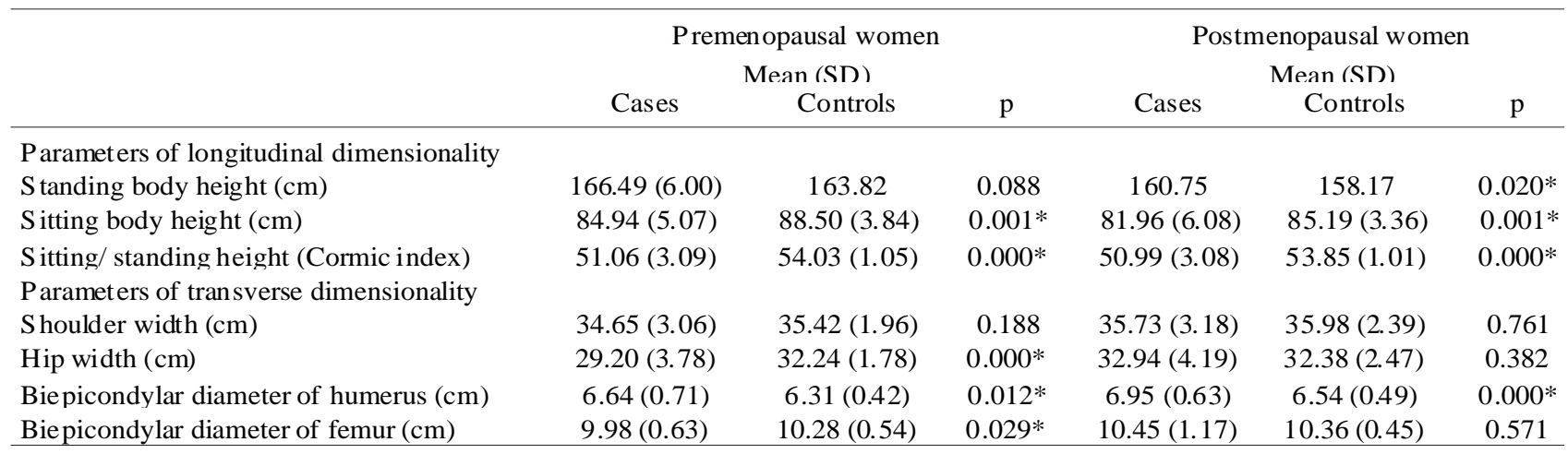


Table III. Body composition parameters in the case and control group.

\begin{tabular}{|c|c|c|c|c|c|c|}
\hline & \multicolumn{3}{|c|}{$\begin{array}{c}\text { Premenopausal women } \\
\text { Mean (SD) }\end{array}$} & \multicolumn{3}{|c|}{$\begin{array}{c}\text { Postmenopausal women } \\
\text { Mean (SD) }\end{array}$} \\
\hline & Cases & Controls & $\mathrm{p}$ & Cases & Controls & $\mathrm{p}$ \\
\hline Body weight (kg) & $65.10(8.67)$ & $70.13(15.72)$ & 0.114 & $71.25(13.70)$ & $74.78(11.55)$ & 0.126 \\
\hline $\operatorname{BMI}\left(\mathrm{kg} / \mathrm{m}^{2}\right)$ & $23.56(3.54)$ & $26.03(5.16)$ & $0.025^{*}$ & $27.60(5.19)$ & $29.91(4.59)$ & $0.010^{*}$ \\
\hline Fat mass $(\%)$ & $29.68(6.40)$ & $30.54(7.27)$ & 0.601 & $38.54(6.08)$ & $40.09(5.27)$ & 0.135 \\
\hline Fat mass (kg) & $20.02(6.64)$ & $22.43(10.04)$ & 0.250 & $27.92(8.59)$ & $30.46(7.70)$ & 0.085 \\
\hline BAI & $28.82(4.67)$ & $30.66(5.65)$ & 0.143 & $33.53(5.74)$ & $36.40(5.74)$ & $0.005^{*}$ \\
\hline \multicolumn{7}{|c|}{ Circumferences $(\mathrm{cm})$} \\
\hline Upper arm relaxed & $26.93(3.28)$ & $24.53(3.29)$ & $0.003 *$ & $28.90(3.65)$ & $25.47(3.21)$ & $0.000^{*}$ \\
\hline Upper arm flexed & $27.83(3.38)$ & $25.07(3.34)$ & $0.001 *$ & $29.79(3.97)$ & $26.09(3.29)$ & $0.000 *$ \\
\hline Fore arm & $23.78(1.95)$ & $21.91(2.08)$ & $0.000^{*}$ & $24.54(2.66)$ & $22.71(2.08)$ & $0.000^{*}$ \\
\hline Neck & $32.63(1.34)$ & $32.65(1.84)$ & 0.948 & $35.10(3.03)$ & $34.15(2.28)$ & 0.053 \\
\hline Chest & $86.06(6.16)$ & $86.04(7.31)$ & 0.994 & $91.70(8.00)$ & $91.76(7.05)$ & 0.965 \\
\hline Waist & $79.76(10.18)$ & $81.11(15.95)$ & 0.683 & $90.15(13.41)$ & $92.11(13.40)$ & 0.412 \\
\hline Hip & $100.31(7.83)$ & $102.02(12.79)$ & 0.514 & $104.68(9.50)$ & $108.02(9.95)$ & 0.055 \\
\hline Thigh - upper & $55.11(5.05)$ & $51.24(5.51)$ & $0.003 *$ & $54.77(6.43)$ & $51.59(4.39)$ & $0.002 *$ \\
\hline Thigh -middle & $48.22(3.97)$ & $47.59(4.28)$ & 0.517 & $48.23(6.13)$ & $47.91(3.57)$ & 0.731 \\
\hline Thigh - lower & $41.88(3.27)$ & $44.02(3.86)$ & $0.014^{*}$ & $42.76(5.95)$ & $44.07(3.33)$ & 0.144 \\
\hline Calf & $35.79(2.92)$ & $35.13(2.50)$ & 0.299 & $35.72(3.62)$ & $35.52(1.80)$ & 0.713 \\
\hline \multicolumn{7}{|c|}{ Skinfold thicknesses $(\mathrm{mm})$} \\
\hline Subscapular & $19.52(8.75)$ & $21.16(4.91)$ & 0.301 & $23.86(7.70)$ & $23.11(5.14)$ & 0.531 \\
\hline Abdominal & $24.44(9.26)$ & $29.73(6.47)$ & $0.004 *$ & $30.63(10.20)$ & $35.02(6.33)$ & $0.006^{*}$ \\
\hline Supraspinal & $17.50(8.32)$ & $23.53(6.23)$ & $0.001 *$ & $21.76(8.47)$ & $28.47(5.60)$ & $0.000^{*}$ \\
\hline Triceps & $24.32(8.39)$ & $23.17(4.35)$ & 0.439 & $26.93(7.98)$ & $25.45(3.85)$ & 0.210 \\
\hline Biceps & $14.47(6.05)$ & $18.87(5.47)$ & $0.002 *$ & $18.14(8.23)$ & $20.66(6.08)$ & 0.058 \\
\hline Lateral forearm & $13.24(5.96)$ & $12.58(3.30)$ & 0.536 & $13.18(5.72)$ & $13.60(4.22)$ & 0.647 \\
\hline Anterior forearm & $10.25(4.16)$ & $10.56(3.49)$ & 0.727 & $12.01(4.22)$ & $11.48(3.34)$ & 0.439 \\
\hline Thigh & $39.74(11.23)$ & $31.60(5.77)$ & $0.000^{*}$ & $41.18(10.89)$ & $33.21(6.86)$ & $0.000 *$ \\
\hline Calf & $26.52(9.16)$ & $23.50(4.17)$ & 0.054 & $26.81(9.06)$ & $24.43(4.98)$ & 0.083 \\
\hline \multicolumn{7}{|c|}{ Diameters $(\mathrm{cm})$} \\
\hline SAD & $19.31(2.50)$ & $19.58(2.39)$ & 0.647 & $21.76(4.02)$ & $21.51(2.54)$ & 0.688 \\
\hline \multicolumn{7}{|c|}{ Ratios } \\
\hline WHR & $0.80(0.06)$ & $0.79(0.07)$ & 0.694 & $0.85(0.12)$ & $0.85(0.08)$ & 0.949 \\
\hline WHtR & $0.49(0.07)$ & $0.50(0.09)$ & 0.725 & $0.55(0.11)$ & $0.58(0.08)$ & 0.107 \\
\hline WTR & $1.45(0.13)$ & $1.59(0.27)$ & $0.012 *$ & $1.64(0.30)$ & $1.79(0.26)$ & $0.003 *$ \\
\hline SADH & $0.12(0.02)$ & $0.12(0.01)$ & 0.300 & $0.13(0.03)$ & $0.14(0.02)$ & 0.816 \\
\hline ADI & $0.40(0.04)$ & $0.41(0.04)$ & 0.292 & $0.45(0.08)$ & $0.45(0.06)$ & 0.752 \\
\hline BSI & $0.07(0.01)$ & $0.07(0.01)$ & 0.056 & $0.08(0.01)$ & $0.07(0.01)$ & 0.089 \\
\hline
\end{tabular}

Table IV. Comparison of case and control group on somatotype components.

\begin{tabular}{|c|c|c|c|c|c|c|}
\hline & \multicolumn{3}{|c|}{$\begin{array}{c}\text { Premenopausal women } \\
\text { Mean (SD) }\end{array}$} & \multicolumn{3}{|c|}{$\begin{array}{c}\text { Postmenopausal women } \\
\text { Mean (SD) }\end{array}$} \\
\hline & Cases & Controls & $\mathrm{p}$ & Cases & Controls & $\mathrm{p}$ \\
\hline Endomorphy & $5.84(1.78)$ & $6.55(0.96)$ & $0.027 *$ & $6.89(1.52)$ & $7.37(0.86)$ & $0.035^{*}$ \\
\hline Mesomorphy & $4.50(1.66)$ & $4.19(1.24)$ & 0.356 & $6.10(2.04)$ & $5.37(1.34)$ & $0.022 *$ \\
\hline Ectomorphy & $2.05(1.30)$ & $1.41(0.99)$ & $0.018^{*}$ & $1.06(0.90)$ & $0.68(0.56)$ & $0.007 *$ \\
\hline
\end{tabular}

Most represented somatotype among breast cancer patients was mesomorph-endomorph while the most healthy controls was mesomorphic endomorph (Figs. 1 and 2). 


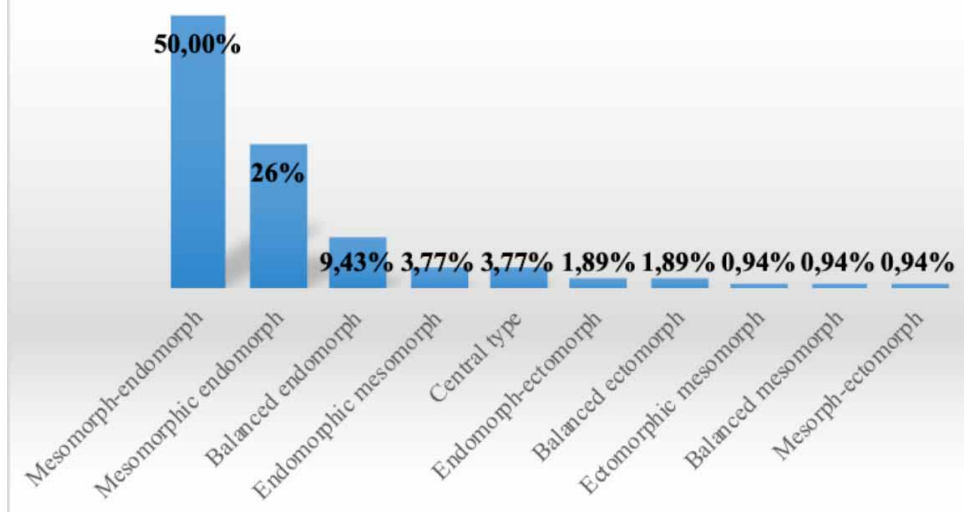

Fig. 1. Somatotype categories in the case group.

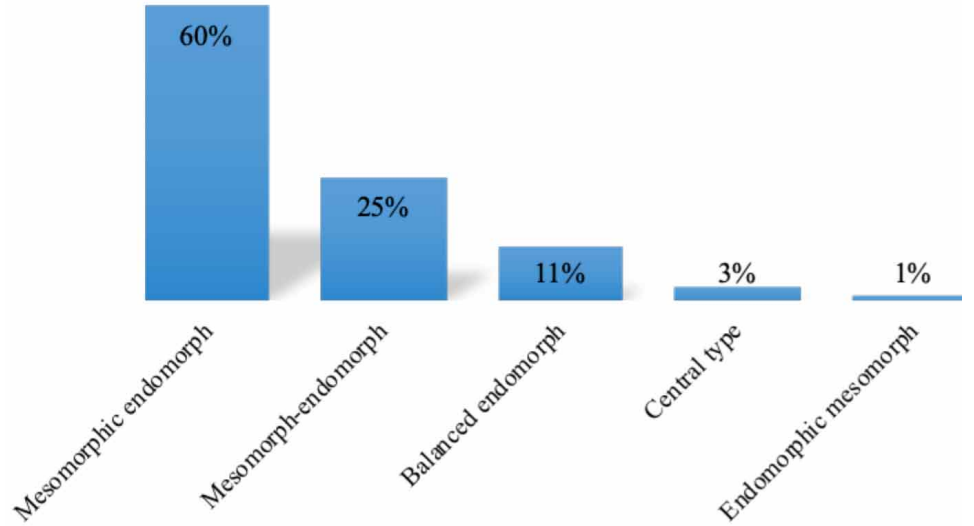

tissue inflammation in obese postmenopausal women is followed with augmented production of androstenedione and aromatase activity contributing to estradiol production and disturbed balance between estradiol and progesterone blood concentration (O'Neill et al., 1988; Bulun et al., 1993; Baglietto et al., 2009) that could cause proliferation of oestrogen dependent tissue such as breast and endometrium and lead to the development of oestrogen dependent tumours in menopause (Morris et al., 2011; Subbaramaiah et al., 2012). In accordance with previously mentioned, the study of Huang et al. (1997) found an increase of $12 \%$ in the risk of breast cancer development in postmenopausal women for every rise of BMI for $5 \mathrm{~kg} / \mathrm{m}^{2}$. However, in premenopausal women risk of breast cancer development has been shown not to be strongly correlated with obesity (Amadou et al., 2013a) which could be justified with reduced oestrogen level due to its storage in adipose tissue, more frequent occurrence of anovulatory and longer menstrual cycles or lower level of progesterone in obese premenopausal women (Henderson et al., 1985; Harvie et al.; Tehard \& Clavel-Chapelon; Dowsett \& Folkerd, 2015). The studies of Suzuki et al. (2009), Rose \& Vona-Davis and White et al. (2015) confirmed this relationship finding that obesity in premenopausal women increases the risk of breast cancer for only $20 \%$ in comparison to postmenopausal women where that risk was estimated to be $82 \%$ (Suzuki et al.) or even reduced the risk for $7 \%$ (White et al.). Moreover, Lahmann et al., demostrated that BMI in premenopausal women negatively correlated to the risk of breast cancer, but it was not statistically significant. Our study showed significantly lower BMI in both, pre- and postmenopausal breast cancer patients. We believe that small number of obese premenopausal women in our research and limited BMI range could elucidate our inverse relationship between BMI and cancer risk among our participants since in the study van den Brandt et al., was reported that decreased breast cancer risk in obese premenopausal women was limited predominantly to the women whose BMI was higher than $31 \mathrm{~kg} / \mathrm{m}^{2}$. On the other hand, as there were no differences in body weight and overall fat mass, differences in BMI in our study obviously have resulted from significantly different body height values. Our results did not confirm relationship between obesity and breast cancer but they are in line with results of studies by van de Brandt, Lahmann and Friendereich that showed that among anthropometric indicators body height is the factor, most often associated with increased risk of breast cancer development in postmenopausal women (van den Brandt et al.; Friedenreich; 
Lahmann et al.). In our research difference in body height was shown to be statistically significant since postmenopausal women suffering from breast cancer were about $2.5 \mathrm{~cm}$ taller than healthy women. Additionally, ectomorphy was also higher in all breast cancer patients pointing to higher body linearity. According to the data for the population of Vojvodina (Pavlica et al., 2010a,b) where this research was conducted, average body heights of women of different ages are: $164.6 \pm 6.7 \mathrm{~cm}(20-29 y)$, $163.9 \pm 6.0$ (30-39y), $161.6 \pm 6.2 \mathrm{~cm}(40-49 \mathrm{y}), 159.6 \pm 6.0$ $\mathrm{cm}(50-59 \mathrm{y})$ and $157.3 \pm 7.5 \mathrm{~cm}(>60 \mathrm{y})$. These results correspond with values in our control group.

In the large study of Lahmann et al. which included 73542 premenopausal and 103344 postmenopausal women from 9 European countries noticed that body height was also higher in women with breast cancer (Friedenreich). It is supposed that the association between height and breast cancer risk could be clarified by the fact that body height sets the number of the fetal ductal stem cells in breasts (Trichopoulos \& Lipman, 1992) and that nutrition, besides determining the body height, has impact on the release of growth hormone and IGF-1 level consequently effecting mammary gland development and carcinogenesis (Stoll, 1992). In our study, measurements of the standing and sitting height as well as the values of Cormic index indirectly speak in favor of greater leg length in pre- and postmenopausal breast cancer women. This finding was not unexpected since the leg length is supposed to be the best indicator of organism exposure to growth hormone effect during early period of life and different nutritional and other external factors and was in accordance with Gunnell et al. (2001), who pointed to a positive correlation between greater stature and leg length with prostate, testicular and premenopausal breast cancer possibly explained by higher level of IGF-1 in these people responsible for apoptosis control and carcinogenesis. Moreover, studies of Mellemkjær et al. (2012) and Fagherazzi et al. found leg length to be important risk factor in breast cancer development. In accordance with the results of Lahmann et al., we found that the ratio between sitting and standing height was lower in cases than controls (Friedenreich). In our study among the parameters of skeletal dimensions, humerus diameter was found to be significantly greater in women with breast cancer. Pacholczak et al. in their study revealed similar results, finding larger humerus diameter in pre- and postmenopausal women breast cancer patients. In the same study it was hypothesized that in overweight postmenopausal women with breast cancer, higher concentrations of oestrogen during lifetime causes earlier bone maturation, as well as reduction in bone resorption, which could be responsible for greater bone diameters in these women. In addition to this, there is also the effect of androgens which can induce periosteal bone expansion (Vanderschueren et al., 2004). On the other hand, our results showed lower diameter of femur and hip width in premenopausal breast cancer patients.

Besides BMI frequently used as indicator of overall obesity, waist circumference and WHR pointing to central adiposity related to hormonal and metabolic changes, are believed to be better predictors of breast cancer risk (Huang et al., 1999). Although White et al. confirmed this relationship finding positive correlation between waist circumference and breast cancer risk, in our research this indicator was not significantly higher in breast cancer patients and in the study of Tehard \& Clavel-Chapelon the correlation was even negative in pre- and only weakly positive in postmenopausal women. Besides that, while in the study of Pacholczak et al., WHR in premenopausal women was found to be significantly higher in study than control group in our study values of WHR in premenopausal women did not show significant differences between study and control group. Additionally, among postmenopausal women, neither the previously mentioned study nor our study significantly differ in WHR (Pacholczak et al.). Furthermore, our results showed that thicknesses of supraspinal and abdominal skinfolds known as the truncal adiposity indicators, were significantly higher in healthy subjects compared to study group, while Pacholczak et al. did not spot significant difference in thickness of supraspinal skinfold (Pacholczak et al.). Surprisingly, in our study we did not reveal the expected results indicating to central obesity as a major contributor to breast cancer development. Since it is shown that in premenopausal women estradiol level does not correlate with waist circumference (Freeman et al., 2010) opposite to postmenopausal women where its production in visceral adipose tissue is believed to be related to central adiposity (Calle \& Kaaks, 2004), it might suggest that except oestrogen production other mechanisms like hyperinsulinemia and IGF-1 level could be responsible for higher incidence of breast cancer in centrally obese premenopausal women (White et al.) while in postmenopausal women central adiposity is believed to associate with oestrogen production in visceral adipose tissue. On the other hand, our results showed lower values of central adiposity indices but only for those that included values of body height - this can be explained by significantly higher values of body height in cases.

Among parameters of peripheral adipose tissue size we found significantly higher values of thigh skinfold thickness in pre- and postmenopausal cases, which corresponded with higher upper thigh circumference while lower 
thigh circumference was significantly lower in premenopausal breast cancer patients pointing to greater importance of upper thigh adipose tissue. Also, higher upper thigh circumferences in breast cancer patients were followed with higher upper arm (relaxed and flexed) as well as forearm circumferences. Contrary to the results of Lahmann et al. study which showed that in postmenopausal women hip circumference above $108 \mathrm{~cm}$ increases the risk of breast cancer for $56 \%$ in comparison to women with hip circumference lower than $94 \mathrm{~cm}$, in our study hip circumference was nearly significantly lower in postmenopausal breast cancer patients $(\mathrm{p}=0.055)$. It is supposed that low hip circumference in postmenopausal women is associated with small amount of subcutaneous fat in lower parts of the body followed by lower risk of cardiovascular disease, diabetes mellitus and insulin resistance which could be related to breast cancer development (Parker et al., 2009). Considering adipose tissue distribution, generally speaking, women with breast cancer diagnose are believed to have android body type with adipose tissue distribution predominantly in central and upper parts of the body which is manifested by greater shoulder width, waist circumference, triceps skinfold thickness and subscapular skinfold thickness and, on the other hand, lesser hip circumference and shorter trunk which is assumed to be the consequence of increased androgen level in menopause. Our study confirmed narrow hips in premenopausal breast cancer patients and higher biepicondylar diameter of humerus. Upper arm and forearm circumferences were higher in breast cancer patients, while biceps skinfold thickness was lower indicating higher muscular mass. This is in line with observations of Butova et al., who found lower values of skinfold thicknesses of the upper arm and chest in breast cancer patients.

Among very few studies dealing with somatotype in medicine, the study carried out by Ronco et al. pointed to higher endomorphic component in breast cancer patients, while Butova et al. reported dominance of mesomorphy. However, our results partialy confirmed these findings. Breast cancer patients in our study had significantly lower endomorphy and higher ectomorphy while mesomorphy was higher only in postmenopausal patients. Most cases displayed balanced mesomorph-endomorph somatotype, while the most of controls was mesomorphic endomorphs showing dominance of endomorphic component.

The major limitation of our study would be the small number of participants especially in premenopausal period and with breast cancer diagnosis as well as limited range of BMI in these women.

Our study confirmed higher body height in postmenopausal breast cancer patients. Body weight and body fat mass didn't differ significantly between breast cancer patients and healthy controls, while indicators of central were lower and indicators of peripheral adiposity were greater in breast cancer patients. Women with breast cancer expressed more male anthropometric features like higher stature, shorter trunk, narrower hips, higher biepicondylar diameter of humerus, larger upper- and forearm circumferences followed by lower skinfold thicknesses. Most frequent somatotype among breast cancer patients was mesomorph-endomorph. These results might contribute to better understanding of the role of obesity and adipose tissue distribution in breast cancer development, as well as to reveal specific anthropometric profile associated with breast cancer.

UDICKI, M.; ADAMOVIC, D.; SRDIC GALIC, B.; PAVLICA, T. \& RADOVANOVIC, Z. Características antropométricas y somatotipos de mujeres con cáncer de mama. Int. J. Morphol., 38(2):448-457, 2020.

RESUMEN: La información en la literatura es variable sobre la relación entre el cáncer de mama, la adiposidad, el tamaño corporal y somatotipo de las mujeres. El objetivo de este estudio fue comparar las características antropométricas, la composición corporal y el somatotipo entre pacientes con cáncer de mama y controles sanos. El grupo de estudio consistió en 106 pacientes con cáncer de mama y el grupo de control de 100 mujeres sanas que se sometieron a 29 mediciones antropométricas. Las mujeres con cáncer de mama tenían mayor cantidad características antropométricas masculinas, tal como una estatura más alta $(160.75 \pm 6.91$ vs. $158.17 \pm 4.89 \mathrm{~cm}, \mathrm{p}=0.020)$, tronco más

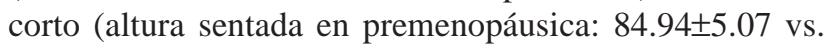
$88.50 \pm 3.84 \mathrm{~cm}, \mathrm{p}=0.001$ y mujeres posmenopáusicas: $81.96 \pm 6.08$ vs. $85.19 \pm 3.36 \mathrm{~cm}, \mathrm{p}=0.001)$, caderas más estrechas $(29.20 \pm 3.78$ vs. $32.24 \pm 1.78 \mathrm{~cm}, \mathrm{p}=0.000)$, mayor diámetro biepicondilar del húmero (premenopáusico: $6.64 \pm 0.71$ vs. $6.31 \pm 0.42 \mathrm{~cm}, \mathrm{p}=0.012$; posmenopáusica: $6.95 \pm 0.63$ vs. $6.54 \pm 0.49 \mathrm{~cm}, \mathrm{p}=0.000$ ), mayor circunferencia del antebrazo y la parte superior del muslo, bíceps inferiores y mayor grosor del pliegue de la piel del muslo. Además se observó una endomorfia significativamente menor (premenopáusica: $5.84 \pm 1.78$ vs. $6.55 \pm 0.96, \mathrm{p}=0.027$; posmenopáusica: $6.89 \pm 1.52$ vs. $7.37 \pm 0.86, \mathrm{p}=0.035)$ y una ectomorfia significativamente más alta (premenopáusica: $2.05 \pm 1.30$ vs. $1.41 .990 .99, \mathrm{p}=0.018$; posmenopáusica: $1.06 \pm 0.90$ vs. $0.68 \pm 0.56, \mathrm{p}=0.007)$, así como una mayor mesomorfia solo en mujeres posmenopáusicas $(6.10 \pm 2.04$ vs. $5.37 \pm 1.34, p=0.022$ ). El somatotipo más representado entre las pacientes con cáncer de mama fue el endomorfomesomorfo, mientras que los controles más sanos fueron el 
mesomórfico endomorfo. Las características del cuerpo tipo androide aumenta el riesgo de desarrollar cáncer de mama. Los indicadores de dimensiones esqueléticas, volumen muscular y adiposidad periférica tuvieron un mejor valor predictivo sobre los marcadores de adiposidad central y general.

PALABRAS CLAVE: Cáncer de mama; Obesidad; Antropometría, Somatotipo.

\section{REFERENCES}

Amadou, A.; Ferrari, P.; Muwonge, R.; Moskal, A.; Biessy, C.; Romieu, I. $\&$ Hainaut, P. Overweight, obesity and risk of premenopausal breast cancer according to ethnicity: a systematic review and dose-response meta-analysis. Obes. Rev., 14(8):665-78, 2013 a.

Amadou, A.; Hainaut, P. \& Romieu, I. Role of obesity in the risk of breast cancer: lessons from anthropometry. J. Oncol., 2013:906495, 2013 b.

Baglietto, L.; English, D.R.; Hopper, J.L.; Maclnnis, R.J.; Morris, H.A.; Tilley, W.D.; Krishnan, K. \& Giles, G.G. Circulating steroid hormone concentrations in postmenopausal women in relation to body size and composition. Breast Cancer Res. Treat., 115:171-9, 2009.

Bergman, R. N.; Stefanovski, D.; Buchanan, T. A.; Sumner, A. E.; Reynolds, J. C.; Sebring, N. G.; Xiang, A. H. \& Watanabe, R. M. A better index of body adiposity. Obesity (Silver Spring), 19(5):1083-9, 2011.

Biglia, N.; Peano, E.; Sgandurra, P.; Moggio, G.; Pecchio, S.; Maggiorotto, F. \& Sismondi, P. Body Mass Index (BMI) and breast cancer: impact on tumor histopathologic features, cancer subtypes and recurrence rate in pre and postmenopausal women. Gynecol. Endocrinol., 29(3):263-7, 2013.

Bulun, S. E.; Mahendroo, M. S. \& Simpson, E. R. Aromatase gene expression in adipose tissue: relationship to breast cancer. J. Steroid Biochem. Mol. Biol., 49(4-6):319-26, 1994.

Bulun, S. E.; Price, T. M.; Aitken, J.; Mahendroo, M. S. \& Simpson, E. R. A link between breast cancer and local estrogen biosynthesis suggested by quantification of breast adipose tissue aromatase cytochrome $\mathrm{P} 450$ transcripts using competitive polymerase chain reaction after reverse transcription. J. Clin. Endocrinol. Metab., 77(6):1622-8, 1993.

Butova, O. A.; Eremin, V. A. \& Seifulina, G. V. Somatotype of women of the stavropol region with mammary gland pathology. Morfologiia, 127(1):46-8, 2005.

Calle, E. E. \& Kaaks, R. Overweight, obesity and cancer: epidemiological evidence and proposed mechanisms. Nat. Rev. Cancer, 4(8):579-91, 2004.

Carter, J. E. L. \& Heath, B. H. Somatotyping: Development and Applications. New York, Cambridge University Press, 1990.

Divella, R.; De Luca, R.; Abbate, I.; Naglieri, E. \& Daniele, A. Obesity and cancer: the role of adipose tissue and adipo-cytokines-induced chronic inflammation. J. Cancer, 7(15):2346-59, 2016.

Dowsett, M. \& Folkerd, E. Reduced progesterone levels explain the reduced risk of breast cancer in obese premenopausal women: a new hypothesis. Breast Cancer Res. Treat., 149(1):1-4, 2015.

Eston, R. G. \& Reilly, T. Kinanthropometry and Exercise Physiology Laboratory Manual: Tests, Procedures and Data. $2^{\text {nd }}$ ed. London, Routledge, 2001.

Fagherazzi, G.; Vilier, A.; Boutron-Ruault, M. C.; Clavel-Chapelon, F. \& Mesrine, S. Height, Sitting Height, and Leg Length in Relation With Breast Cancer Risk in the E3N Cohort. Cancer Epidemiol. Biomarkers Prev., 21(7):1171-5, 2012.
Freeman, E. W.; Sammel, M. D.; Lin, H. \& Gracia, C. R. Obesity and reproductive hormone levels in the transition to menopause. Menopause, 17(4):718-26, 2010.

Friedenreich, C. M. Review of anthropometric factors and breast cancer risk. Eur. J. Cancer Prev., 10(1):15-32, 2001.

Garrisi, V. M.; Tufaro, A.; Trerotoli, P.; Bongarzone, I.; Quaranta, M.; Ventrella, V.; Tomassi, S.; Giannelli, G. \& Paradiso, A. Body mass index and serum proteomic profile in breast cancer and healthy women: a prospective study. PloS One, 7(11):e49631, 2012.

Gunnell, D.; Okasha, M.; Smith, G. D.; Oliver, S. E.; Sandhu, J. \& Holly, J. M. Height, leg length, and cancer risk: a systematic review. Epidemiol. Rev., 23(2):313-42, 2001.

Harvie, M.; Hooper, L. \& Howell, A. H. Central obesity and breast cancer risk: a systematic review. Obes. Rev., 4(3):157-73, 2003.

Henderson, B. E.; Ross, R. K.; Judd, H. L.; Krailo, M. D. \& Pike, M. C. Do regular ovulatory cycles increase breast cancer risk? Cancer, 56(5):1206-8, 1985.

Huang, Z.; Hankinson, S. E.; Colditz, G. A.; Stampfer, M. J.; Hunter, D. J.; Manson, J. E.; Hennekens, C. H.; Rosner, B.; Speizer, F. E. \& Willett, W. C. Dual effects of weight and weight gain on breast cancer risk. JAMA, 278(17):1407-11, 1997.

Huang, Z.; Willett, W. C.; Colditz, G. A.; Hunter, D. J.; Manson, J. E.; Rosner, B.; Speizer, F. E. \& Hankinson, S. E. Waist circumference, waist:hip ratio, and risk of breast cancer in the Nurses' Health Study. Am. J. Epidemiol., 150(12):1316-24, 1999.

Hunter, D. J. \& Willett, W. C. Diet, body size, and breast cancer. Epidemiol. Rev., 15(1):110-32, 1993.

John, E. M.; Sangaramoorthy, M.; Hines, L. M.; Stern, M. C.; Baumgartner, K. B.; Giuliano, A. R.; Wolff, R. K. \& Slattery, M. L. Overall and abdominal adiposity and premenopausal breast cancer risk among Hispanic women: The Breast Cancer Health Disparities Study. Cancer Epidemiol. Biomarkers Prev., 24(1):138-47, 2015.

John, E. M.; Sangaramoorthy, M.; Phipps, A. I.; Koo, J. \& Horn-Ross, P. L. Adult body size, hormone receptor status, and premenopausal breast cancer risk in a multiethnic population: the San Francisco Bay Area Breast Cancer Study. Am. J. Epidemiol., 173(2):201-16, 2011.

Krakauer, N. Y. \& Krakauer, J. C. A new body shape index predicts mortality hazard independently of Body Mass Index. PLoS One, 7(7):e39504, 2012.

Lahmann, P. H.; Hoffmann, K.; Allen, N.; van Gils, C. H.; Khaw, K. T.; Tehard, B.; Berrino, F.; Tjønneland, A.; Bigaard, J.; Olsen, A.; et al. Body size and breast cancer risk: findings from the European Prospective Investigation Into Cancer and Nutrition (EPIC). Int. J. Cancer, 111(5):762-71, 2004.

Lorincz, A. M. \& Sukumar, S. Molecular links between obesity and breast cancer. Endocr. Relat. Cancer, 13(2):279-92, 2006.

Mellemkjær, L.; Christensen, J.; Frederiksen, K.; Baker, J. L.; Olsen, A.; Sørensen, T. I. A. \& Tjønneland, A. Leg length, sitting height and postmenopausal breast cancer risk. Br. J. Cancer, 107(1):165-8, 2012.

Morris, P. G.; Hudis, C. A.; Giri, D.; Morrow, M.; Falcone, D. J.; Zhou, X. K.; Du, B.; Brogi, E.; Crawford, C. B.; Kopelovich, L.; et al. Inflammation and increased aromatase expression occur in the breast tissue of obese women with breast cancer. Cancer Prev. Res. (Phila.), 4(7):1021-9, 2011.

O'Neill, J. S.; Elton, R. A. \& Miller, W. R. Aromatase activity in adipose tissue from breast quadrants: a link with tumour site. Br. Med. J. (Clin. Res. Ed.), 296(6624):741-3, 1988.

Pacholczak, R.; Klimek-Piotrowska, W. \& Kuszmiersz, P. Associations of anthropometric measures on breast cancer risk in pre- and postmenopausal women-a case-control study. J. Physiol. Anthropol., 35:7, 2016.

Parker, E. D.; Pereira, M. A.; Stevens, J. \& Folsom, A. R. Association of hip circumference with incident diabetes and coronary heart disease: The Atherosclerosis Risk in Communities Study. Am. J. Epidemiol., 169(7):837-47, 2009. 
Pavlica, T.; Bozic Krstic, V. \& Rakic, R. Body mass index, waist-to-hip ratio and waist/height in adult population from Backa and Banat the Republic of Serbia. Ann. Hum. Biol., 37(4):562-73, 2010a.

Pavlica, T.; Bozic Krstic, V. \& Rakic, R. Relationship between adult stature, BMI and WHR in Backa and Banat. Anthropol. Anz., 68(1):31$41,2010 b$.

Ronco, A. L.; Mendoza, B.; Varas, X.; Jaumandreu, S.; De Stéfani, E.; Febles, G.; Barboza, R. \& Gateño, M. Somatotype and risk of breast cancer: a case-control study in Uruguay. Rev. Bras. Epidemiol., 11(2):215-27, 2008.

Rose, D. P. \& Vona-Davis, L. Interaction between menopausal status and obesity in affecting breast cancer risk. Maturitas, 66(1):33-8, 2010.

Stoll, B. A. Does extra height justify a higher risk of breast cancer? Ann. Oncol., 3(1):29-30, 1992.

Subbaramaiah, K.; Morris, P.G.; Zhou, X. K..; Morrow, M.; Du, B.; Giri, D.; Kopelovich, L.; Hudis, C. A. \& Dannenberg, A. J. Increased levels of COX-2 and Prostaglandin E2 contribute to elevated aromatase expression in inflamed breast tissue of obese women. Cancer Discov, 2(4):356-65, 2012

Suzuki, R.; Orsini, N.; Saji, S.; Key, T. J. \& Wolk, A. Body weight and incidence of breast cancer defined by estrogen and progesterone receptor status--A meta-analysis. Int. J. Cancer, 124(3):698-712, 2009.

Tehard, B. \& Clavel-Chapelon, F. Several anthropometric measurements and breast cancer risk: results of the $\mathrm{E} 3 \mathrm{~N}$ cohort study. Int. J. Obes. (Lond.), 30(1):156-63, 2006.

Trichopoulos, D. \& Lipman, R. D. Mammary gland mass and breast cancer risk. Epidemiology, 3(6):523-6, 1992.

Ursin, G.; Longnecker, M. P.; Haile, R. W. \& Greenland, S. A metaanalysis of Body Mass Index and risk of premenopausal breast cancer. Epidemiology, 6(2):137-41, 1995.

van den Brandt, P. A.; Spiegelman, D.; Yaun, S. S.; Adami, H. O.; Beeson, L.; Folsom, A. R.; Fraser, G.; Goldbohm, R. A.; Graham, S.; Kushi, L.; et al. Pooled analysis of prospective cohort studies on height, weight, and breast cancer risk. Am. J. Epidemiol., 152(6):514-27, 2000.

Vanderschueren, D.; Vandenput, L.; Boonen, S.; Lindberg, M. K.; Bouillon, R. \& Ohlsson, C. Androgens and bone. Endocr. Rev., 25(3):389-425, 2004.

White, A. J.; Nichols, H. B.; Bradshaw, P. T. \& Sandler, D. P. Overall and central adiposity and breast cancer risk in the sister study. Cancer, 121(20):3700-8, 2015.

Zunurain, Z.; Almardhiyah, A. R. A.; Gan, S. H.; Arifin, W. N.; Sirajudeen, K.; Bhavaraju, V.; Shahar, S. \& Jan, J. M. H. Anthropometric and reproductive factors among newly- diagnosed breast cancer patients and healthy women: a case-control study. Asian Pac. J. Cancer Prev., 17(9):4439-44, 2016.

\section{Corresponding author: Mirjana Udicki, MD, PhD University of Novi Sad Faculty of Medicine Department of Anatomy Hajduk Veljkova 3 21000 Novi Sad SERBIA}

Email: mirjana.udicki@mf.uns.ac.rs

Received: 24-06-2019

Accepted: 09-09-2019 